\title{
Comparative Study of Automation and Conventional System on Production Performance in Poultry Farms
}

\author{
Abhijeet Kumar ${ }^{1 *}$, Prasanna Somerahally Basavaraju ${ }^{2}$, Mahesh Subhash Patlapati ${ }^{3}$, Malathi, $\mathrm{V}^{4}$, \\ Mahadevappa D Gouri ${ }^{5}$, Jayanaik ${ }^{6}$, Vivek M Patil ${ }^{7}$, Jaya Nagappa Lakkundi ${ }^{8}$, Ranjith Roy Yadav ${ }^{9}$ and \\ Prabha Karan ${ }^{10}$ \\ ${ }^{1}$ Central Poultry Development Organization and Training Institute Hessarghatta, Bangalore, INDIA \\ ${ }^{2}$ Department of Livestock Production Management, Veterinary College Hebbal, Bangalore, INDIA \\ ${ }^{3}$ Central Poultry Development Organization and Training Institute Hessarghatta, Bangalore, INDIA \\ ${ }^{4 \varepsilon 6}$ Department of Poultry Science Veterinary College Hebbal, Bangalore, INDIA \\ ${ }^{5}$ Department of Livestock Farm Complex, Veterinary College Hebbal, Bangalore, INDIA \\ ${ }^{7}$ Livestock Research Instruction Complex, Deoni Farm, Veterinary College Bidar, INDIA \\ ${ }^{8}$ Department of Veterinary Parasitology, Veterinary College Hebbal, Bangalore, INDIA \\ ${ }^{9}$ MVSc Scholars Department of Livestock Production Management, Veterinary College Hebbal, Bangalore, INDIA \\ ${ }^{10}$ Class Veterinary Hospital, Girihinda Chowk, Govt of Bihar, INDIA \\ *Corresponding author: Kumar A; E-mail:dr.abhikumar0501@gmail.com
}

Received: 28 Dec., 2020

Revised: 22 Jan., 2021

Accepted: 27 Jan., 2021

\begin{abstract}
The study was conducted to compare the productivity performance of Layer breeder under conventional house and automatic house. Both houses were studied under small farms with an average of 250 birds. This study covered a period of 22 weeks with five replicates. Based on the results, the effect of different rearing systems on the mean body weight and FCR from week eighteen to forty weeks of age on weekly and cumulative basis were significantly $(\mathrm{P} \leq 0.05)$ influenced among the various treatment groups in $\mathrm{HH}-260$ birds. Egg production, Hen housed and hen day egg production in experimental birds in automatic rearing system was significantly different from birds reared in conventional rearing system. The study also concluded that ARS birds had better liveability as compared to birds under conventional rearing systems. Litter quality analyzed based on the proximate analysis and $E$. coli count and found significant $(\mathrm{P} \leq 0.01)$ difference among the two-rearing systems. The proximate analysis of built up litter was significant higher $(\mathrm{P} \leq 0.01)$ in $\mathrm{CRS}$ than the ARS. The higher proximate values like crude protein, crude fat, crude fibre, total ash and energy value were mainly due to feed wastage in conventional rearing system which leads to elevation of these values. There was highly significant difference $(\mathrm{P} \leq 0.01)$ in working time measurement of automation over conventional system of rearing. It accepted the hypothesis of the study that ARS housing have better productivity and profitability over conventional, this is testified by the general better FCR, egg production, liveability and litter quality in CCS houses.
\end{abstract}

\section{HIGHLIGHTS}

( Impact of rearing system on production parameters of layer breeders was studied.

(0 Automatic rearing system has significant influence on growth performance, egg production, liveability, litter quality and working time measurement.

Keywords: Feed conversion ratio, Conventional rearing system (CRS), Automatic rearing system (ARS), litter quality

How to cite this article: Kumar, A., Basavaraju, P.S., Patlapati, M.S. Malathi, V., Gouri, M.D., Jayanaik, Patil, V.M., Lakkundi, J.N., Yadav, R.R. and Karan, P. (2021). Comparative study of automation and conventional system on production performance in poultry farms. J. Anim. Res., 11(1) 187-197.

Source of Support: None; Conflict of Interest: None 
Poultry sector is one of the fastest growing segments of the agricultural and agriculture allied sector in India. The poultry sector in India has undergone a paradigm shift in structure and operation which has been its transformation from a mere backyard activity into a major commercial agro based industry over a period of four decades. The constant efforts in up gradation, modernization and application of new sensor technologies paved the way for the multifaceted growth in poultry and its allied sectors. The development is not only in capacity but also in productivity, sophistication and quality. According to (BAHS, 2019; 20 th Livestock census, 2019), India ranks third in egg production and fifth in broiler production having 851.81 million poultry population with a growth rate of 8.5 per cent. The annual production of eggs has reached to 103.32 billion. Majority of the poultry owners follow the open house conventional rearing system. Farmers are reluctant or hesitate to opt the modern technologies because of easy availability of manpower and their inability to invest on higher short-term capital costs. The trend in poultry production has been towards large commercial farming. This compels the farmers to switch over from traditional practices to mechanized farming which saves time and labour. This includes mechanical cleaning equipment; sensor driven automatic feeding and nipple watering equipment, medication etc. The use of modern technologies makes it possible for large number of bird to be handled in the large scale operation. Controlled feeding and automating a controlled feeding system of broiler for optimum nutrition is a beneficial step and must be applied in poultry enterprises.

The objective of study is to compare the automated system over conventional system on growth performance, age at sexual maturity egg production, egg quality, Per cent settable eggs, fertility, hatchability, litter quality, chick's quality, liveability and working time measurement in deep litter layer breeder farm.

\section{MATERIAL AND METHODS}

In order to achieve the proposed objectives, experiment duration of 22 weeks was conducted at the Central Poultry Development Organization and Training Institute (CPDO \& TI) Hessaraghatta Bengaluru. The experimental procedures and analytical techniques adopted during the course of the study are detailed here. The trial was conducted by using Hessaraghatta hybrid -260 (HH260, White Leg horn breed) layer breeder birds. Eighteen week layer breed numbering 290 (250 females +40 males) were housed in shed No-2 having dimension of $20 \mathrm{ft} \times 50 \mathrm{ft}$. The birds with an average body weight of 1.1 to $1.3 \mathrm{~kg}$ were selected randomly and assigned to 2 groups (T1Conventional rearing system and T2-Automated rearing system), one each for automated and conventional system, with 5 replicates in each group and having 25 female and 4 males in each replicate (125 female per treatment). The chicks were reared in open sided house under deep litter system with all standard management practices till 40 weeks of age. Standard vaccination schedule was followed for immunizing the chicks. Birds were fed with layer breeder ration diet from eighteen weeks @ 120 gm/ bird/day. Feeding of diets commenced at eighteen week of age and continued till the termination of experiment at forty weeks of age.

\section{Parameters studied}

Body weight: The body weights of individual birds were recorded from eighteen weeks of age and at the end of each week till forty weeks of age to monitor the pattern of body weight gain. The weighing of the birds was done in the early hours of the day before feeding by using digital weighing balance.

Feed to egg conversion ratio (FCR): The feed to egg conversion ratio (FCR) expressed as the ratio of amount of feed consumed $(\mathrm{kg})$ per dozen of eggs under each experimental group from twenty third weeks to forty weeks and also determined on cumulative basis. The FCR was calculated by using the following formula:

Feed conservation ratio $(\mathrm{PCR})=$

Average feed consumption per bird per week

Number of eggs produced per week

Age at sexual maturity and egg production: Age at sexual maturity (days) was recorded when the hen laid her first egg. Age at 50 per cent of flock came into production (days) was also recorded. Egg production was calculated on weekly basis. Hen day egg production (HDEP) and Hen housed egg production for a period (HHEP) was calculated at the end of the trial (40 weeks of age). 
Litter Quality: The objective of assessing the litter quality in this experiment was to check the feed wastage in automation and conventional rearing system. Litter quality was assessed based on moisture per cent, proximate principles, microbial load (Esherichia coli) and coccidial oocyst load recorded at the time of sexual maturity and at the end of trial. The following methods were opted for assessing the litter quality:

Table 1: Methods opted for assessing the Litter quality parameters

\begin{tabular}{|c|c|c|}
\hline $\begin{array}{l}\text { Sl. } \\
\text { No. }\end{array}$ & Parameters & Method of Estimation \\
\hline 1 & Moisture & Oven drying (AOAC,2003) \\
\hline 2 & Crude Protein & Kjeldahl methods (AOAC,2003) \\
\hline 3 & Crude Fibre & $\begin{array}{l}\text { Near Infrared reflectance spectroscopy } \\
\text { (Tyagi et al., 2009) }\end{array}$ \\
\hline 4 & Ether Extract & Soxhlet method (AOAC,2003) \\
\hline 5 & Total Ash & Dry Ashing (AOAC,2003) \\
\hline 6 & E. coli & MacConkey Agar media (Aryal, 2018) \\
\hline 7 & $\begin{array}{l}\text { Coccidial } \\
\text { oocyst }\end{array}$ & $\begin{array}{l}\text { McMaster egg counting technique (Haug } \\
\text { et al., 2006) }\end{array}$ \\
\hline
\end{tabular}

Liveability: Liveability was calculated with the given formula at the end of the trial for the birds under each treatment

Working Time Measurement: Time and motion study comprising of time taken in feeding, watering, medication in automation and conventional system were calculated. A timer was fixed for each routine work and separately calculated for automation and conventional system (Armstrong and Quick, 1986).

\section{RESULTS AND DISCUSSION}

Body weight: The effects of different rearing system (Table 2) on the mean body weight from eighteen to forty weeks of age on weekly basis were significantly $(\mathrm{P} \leq 0.05)$ influenced among the various treatment groups in $\mathrm{HH}-$ 260 birds. The body weights of both the treatment groups were uniform till thirty weeks $(\mathrm{P} \leq 0.05)$. From thirty-one to forty weeks optimum body weight achieved in birds reared in automatic rearing system as compare to birds reared in conventional rearing system. This shows that the uniform feeding achieved in automatic rearing system as compare to conventional rearing system.
Table 2: Effect of rearing systems on weekly average body weight (kgs) of HH-260 birds

\begin{tabular}{|c|c|c|c|}
\hline \multirow{2}{*}{$\begin{array}{l}\text { Age } \\
\text { (Weeks) }\end{array}$} & \multicolumn{2}{|c|}{ Rearing systems } & \multirow{2}{*}{ P Value } \\
\hline & Automation & Conventional & \\
\hline $18^{\text {th }}$ & $1.211 \pm 0.01$ & $1.212 \pm 0.05$ & 0.912 \\
\hline $19^{\text {th }}$ & $1.272 \pm 0.01$ & $1.278 \pm 0.04$ & 0.635 \\
\hline $20^{\text {th }}$ & $1.328 \pm 0.01$ & $1.326 \pm 0.01$ & 0.909 \\
\hline $21^{\text {st }}$ & $1.360 \pm 0.01$ & $1.352 \pm 0.01$ & 0.524 \\
\hline $22^{\text {nd }}$ & $1.390 \pm 0.02$ & $1.371 \pm 0.04$ & 0.145 \\
\hline $23^{\text {rd }}$ & $1.420 \pm 0.01$ & $1.410 \pm 0.05$ & 0.509 \\
\hline $24^{\text {th }}$ & $1.452 \pm 0.04$ & $1.426 \pm 0.06$ & 0.784 \\
\hline $25^{\text {th }}$ & $1.488^{\mathrm{a}} \pm 0.03$ & $1.438^{\mathrm{b}} \pm 0.06$ & 0.042 \\
\hline $26^{\text {th }}$ & $1.516 \pm 0.04$ & $1.450 \pm 0.07$ & 0.241 \\
\hline $27^{\text {th }}$ & $1.536 \pm 0.05$ & $1.454 \pm 0.05$ & 0.281 \\
\hline $28^{\text {th }}$ & $1.566 \pm 0.23$ & $1.464 \pm 0.42$ & 0.735 \\
\hline $29^{\text {th }}$ & $1.574 \pm 0.41$ & $1.476 \pm 0.35$ & 0.583 \\
\hline $30^{\text {th }}$ & $1.587 \pm 0.69$ & $1.494 \pm 0.52$ & 0.058 \\
\hline $31^{\text {st }}$ & $1.612 \pm 0.21$ & $1.515 \pm 0.33$ & 0.181 \\
\hline $32^{\text {nd }}$ & $1.624 \pm 0.12$ & $1.531 \pm 0.47$ & 0.545 \\
\hline $33^{\mathrm{rd}}$ & $1.644^{\mathrm{a}} \pm 0.25$ & $1.541^{\mathrm{b}} \pm 0.11$ & 0.011 \\
\hline $34^{\text {th }}$ & $1.672 \pm 0.41$ & $1.565 \pm 0.84$ & 0.195 \\
\hline $35^{\text {th }}$ & $1.681 \pm 0.27$ & $1.572 \pm 0.43$ & 0.161 \\
\hline \multirow[t]{2}{*}{$36^{\text {th }}$} & & $1.580^{\mathrm{B}} \pm 0.54$ & 0.010 \\
\hline & $1.688^{\mathrm{A}} \pm 0.36$ & & \\
\hline $37^{\text {th }}$ & $1.697 \pm 0.73$ & $1.591 \pm 0.51$ & 0.081 \\
\hline $38^{\text {th }}$ & $1.712 \pm 0.26$ & $1.602 \pm 0.37$ & 0.092 \\
\hline $39^{\text {th }}$ & $1.715 \pm 0.33$ & $1.608 \pm 0.22$ & 0.063 \\
\hline $40^{\text {th }}$ & $1.721 \pm 0.32$ & $1.611 \pm 0.44$ & 0.074 \\
\hline
\end{tabular}

A,B-Means bearing different superscripts within rows differ significantly $(\mathrm{P} \leq 0.01)$; a,b- Means bearing different superscripts within rows differ significantly $(\mathrm{P} \leq 0.05)$.

The results of present study are in agreement with Lacin et al. (2008) findings as uniform feeding has positive influence on achieving optimum body weight. Leeson and Summers (1991) and Harms et al. (1984) noted that there was a significant relationship between feed consumption and body weight. Maximum body weight was found in $T_{1}$ group (ARS) which was not significantly high as compared to $\mathrm{T}_{2}$ group groups during forty week of the experiment. Anderson and Adams (1994) indicated that birds provided with more feeder space will gain the bodyweight faster in white leg horn birds. This follows the same trends found by Anderson and Adams (1992) i.e., (Body weight differences manifested at the end of the rearing period remained 
through the production cycle). They also concluded that ending $\mathrm{BW}$ and $\mathrm{BW}$ gain were not affected by the type of flooring material. In contrast of Meunier-Salaun et al. (1984), who reported that the rearing environment had no significant effects on hen performance. Breeder management guide programs have suggested that optimum feeder space will ensure that all chicken have access to the feed and that feeder space should increase as the chicken's age (Anonymous, 1997). Furthermore, inadequate feeder space has been generally associated with poor uniformity of flock BW (Anonymous, 2009), but a controlled study found that significantly reduced feeder space had no effect on BW uniformity (Van Krey and Weaver, 1988). Singh et al. (2009) also reported that the body weight of hens will be affected by different rearing system. Uniformity of body weight in pullets and layers is of an important managerial concern (Sosnówka et al., 2010). However, on contrary (Adam, 2017) study showed no significant differences in body weight gain during the experimental period for layers housed in different rearing system.

Feed Conversion ratio: Statistical analysis revealed significant difference $(\mathrm{P} \leq 0.01)$ in mean FCR values (Table 3 ) among the two treatment groups during twenty third week, twenty nine week, thirty week, thirty one week, thirty nine and forty week. The patented Roxell Haikoo feeder ${ }^{\circledR}$ designed in such a way that it accommodate more number of birds compare to conventional feeders, which further leads to the optimum feed utilization by the birds. The results of present study are in agreement of Sonkamble et al. (2020) findings that feed conversion ratio in terms of feed intake/ egg was influenced by type of rearing systems. Contrary to our findings in this experiment, the results of the present study are in disagreement with Ahammed et al. (2014) who reported that there was no significant difference in feed conversion ratio in birds reared in different rearing systems. Conflicting reports from those authors is likely due to the influence of a variety of factors, such as genetics, nutrition, environment, and age (Rakonjac et al., 2017). Regarding the genetics of the bird, it is suggested that commercial strain, selected for production under intensive controlled conditions, seem to be inappropriate for alternative and enriched rearing systems, which provide more natural but poorer living conditions (Hovi et al., 2003). However, there was no information regarding the effect of automatic rearing systems on white leghorn chicken (HH-260). Although many researchers have studied laying hen performance response to automatic and alternative rearing systems such as enriched cage, aviary, floor management, and free range systems (Tauson et al., 1999; Neijat et al., 2011; Ahammed et al., 2014), studies on the effect of changing from conventional cages to automatic rearing systems on production traits are continuing, especially in relation to the ability of pure inbred breeds to adapt to these automatic systems under certain climates. Hens under automatic rearing systems (ARS) showed higher FCR, this was probably due to the higher motor activity (Castellini et al., 2006) of the hens of this group. This statement is consistent with report from Lampkin (1997) and Mugnai et al. (2009).

Table 3: Effect of rearing systems on weekly Feed Conversion Ratio (feed consumed in kg per dozen egg) of HH260 birds

\begin{tabular}{|c|c|c|c|}
\hline \multirow{2}{*}{$\begin{array}{l}\text { Age } \\
\text { (Weeks) }\end{array}$} & \multicolumn{2}{|c|}{ Rearing systems } & \multirow{2}{*}{ P Value } \\
\hline & Automation & Conventional & \\
\hline $23^{\text {rd }}$ & $2.575^{\mathrm{A}} \pm 0.05$ & $3.328^{\mathrm{B}} \pm 0.12$ & 0.009 \\
\hline $24^{\text {th }}$ & $2.574 \pm 0.08$ & $2.726 \pm 0.08$ & 0.27 \\
\hline $25^{\text {th }}$ & $1.993 \pm 0.02$ & $2.110 \pm 0.09$ & 0.33 \\
\hline $26^{\text {th }}$ & $1.844 \pm 0.01$ & $1.826 \pm 0.06$ & 0.75 \\
\hline $27^{\text {th }}$ & $1.861 \pm 0.03$ & $1.854 \pm 0.07$ & 0.89 \\
\hline $28^{\text {th }}$ & $1.769 \pm 0.07$ & $1.865 \pm 0.04$ & 0.1 \\
\hline $29^{\text {th }}$ & $1.728^{\mathrm{A}} \pm 0.01$ & $1.876^{\mathrm{B}} \pm 0.08$ & 0.01 \\
\hline $30^{\text {th }}$ & $1.868^{\mathrm{A}} \pm 0.02$ & $1.981^{\mathrm{B}} \pm 0.04$ & 0.002 \\
\hline $31^{\mathrm{st}}$ & $1.849^{\mathrm{A}} \pm 0.04$ & $2.560^{\mathrm{B}} \pm 0.06$ & 0.009 \\
\hline $32^{\text {nd }}$ & $1.917^{\mathrm{a}} \pm 0.05$ & $2.373^{b} \pm 0.08$ & 0.042 \\
\hline $33^{\text {rd }}$ & $2.132 \pm 0.08$ & $2.246 \pm 0.04$ & 0.68 \\
\hline $34^{\text {th }}$ & $2.148 \pm 0.02$ & $2.236 \pm 0.07$ & 0.16 \\
\hline $35^{\text {th }}$ & $2.148 \pm 0.03$ & $2.202 \pm 0.05$ & 0.78 \\
\hline $36^{\text {th }}$ & $2.184^{\mathrm{A}} \pm 0.04$ & $2.437^{\mathrm{B}} \pm 0.04$ & 0.095 \\
\hline $37^{\text {th }}$ & $2.244 \pm 0.03$ & $2.356 \pm 0.03$ & 0.67 \\
\hline $38^{\text {th }}$ & $2.348 \pm 0.06$ & $2.437 \pm 0.09$ & 0.56 \\
\hline $39^{\text {th }}$ & $2.654 \pm 0.07$ & $2.511 \pm 0.08$ & 0.59 \\
\hline $40^{\text {th }}$ & $2.892 \pm 0.08$ & $2.845 \pm 0.04$ & 0.87 \\
\hline
\end{tabular}

A,B-Means bearing different superscripts within rows differ significantly $(\mathrm{P} \leq 0.01)$; a,b- Means bearing different superscripts within rows differ significantly $(\mathrm{P} \leq 0.05)$.

This study shows the ability of layers hens to regulate the intake of nutrients which can be used to increase feed efficiency. Greater levels of comfort behaviours such as resting, and preening, perching and mud bathing had shown improved FCR in the white leg horn birds. Clark 
et al. (2019) also had similar study and concluded that significant impact of comfort behaviours such as resting, perching, mud bathing and preening on Feed conversion ratio. Poultry birds are good foragers and converters of feed into bio-available protein in meat and egg (Abanikannda et al., 2007). Feed conversion ratio for the entire laying period, the best-feed conversion ratio was observed in layers reared in deep-litter system (Adam, 2017). Also report noted by (Gerzilov, 2012) the feed conversion ratio in layers kept in deep-litter was high versus other both poultry housing systems.

Age at sexual maturity: Age at first egg of the experimental birds (Table 4) was considered as age at sexual maturity during the study. There was no significant difference observed in age at sexual maturity in relation to the rearing system. Age at first egg in both the treatment group did not have impacted on experimental birds since all the experimental birds selected at the age of eighteen weeks. And also, automatic and conventional rearing system did not have significant effects on age at fifty per cent production. The result of the study is in agreement with the findings of Sonkamble et al. (2020) as the rearing of birds in different housing system did not have significant effects on age at first egg and age at sexual maturity. Similar results were reported by Anderson and Adam (1994) that rearing feeder space had no effect on the age at 50 per cent production and age at sexual maturity. On contrary to these findings, DeAvila et al. (2003) reported that feeding time and frequency triggers early sexual maturity in female broilers breeders.

Table 4: Effect of rearing systems on age at sexual Maturity of HH260 birds

\begin{tabular}{lll}
\hline Rearing system & $\begin{array}{l}\text { Age at first egg } \\
\text { produced(days) }\end{array}$ & $\begin{array}{l}\text { Age at 50\% production } \\
\text { (days) }\end{array}$ \\
\hline Automation & $133.98 \pm 0.05$ & $147.66 \pm 0.08$ \\
Convention & $134.54 \pm 0.03$ & $154 \pm 0.04$ \\
P value & 0.24 & 0.15 \\
\hline
\end{tabular}

Egg Production: Egg production in experimental birds (Table 5a) in automatic rearing system was significantly different $(\mathrm{P} \leq 0.05)$ from birds reared in conventional rearing system. Similarly, Hen housed egg production and Hen day egg production (Table 5 b) was significantly higher $(\mathrm{P} \leq 0.01)$ in automatic rearing system as compare to conventional rearing system. The result of the study are in agreement with the findings of Idowu et al. (2018) as rearing system have positive correlation to the egg production. Similar study conducted by Englmaierová et al. (2014) reported the highest hen day egg production found in enriched rearing system than other rearing system. Egg production is partly productive and partly reproductive trait (Bell et al., 2007). Improving feed conversion ratio and achieving optimum body weight will improve the total egg production. It can be statistically induced that selection for improving one trait will simultaneously improve the other traits and otherwise. This result agrees with Jahan et al. (2017). However, on contrary to the findings of Du Plessis, (1972) reported that there is no relationship between total egg production and body weight at sexual maturity. Some studies (Abrahamsson et al., 1996; Tauson et al., 1999) have reported that egg production of laying hens was influenced by rearing system. The managemental factors like optimum feeding, watering and less manhandling will reduce the stress in the birds which in turn reduce the plasma cortisone level of the experimental birds (Scanes, 2016). Tactacan et.al. (2009) studied the comparison of conventional versus enriched house concluded that there was no marked difference in hen day egg production. Poultry hen requires about 24 to 26 hours for producing an egg. After the egg is laid, the hen starts all over again about 30 minutes later (Bell et al., 2007).Egg production is a dependent variable and is influenced by several factors like strain of chicken (Shah et al., 2006; Petek, 1999), feeding, mortality, culling, health and management practices, age at point-of-lay, and peak for lay and persistency of lay rate (Kristensen and Silleb-Kristensen 1996). Some important factors from the managerial point of view efficient operations, resources utilization, economical feeding, improved housing and standard stocking density rate (Eekeren, 2006). Egg production can be environmentally affected by factors such as quality and quantity of poultry feed, water consumption intensity, photoperiodism and diseases (Kekeocha, 1984). In contrast to the findings of Sonkamble et al. (2020), who reported that the average hen day and hen house egg production were not affected due to different housing systems. Similar study reported that egg production of hens showed no difference under different rearing systems (Neijat et al., 2011; Ahammed et al., 2014). 
Table 5(a): Effect of rearing systems on egg production (No's \& $\%$ in $\mathrm{HH}-260$ birds

\begin{tabular}{|c|c|c|c|c|c|}
\hline \multirow[b]{2}{*}{$\begin{array}{c}\text { Age } \\
\text { (Days) }\end{array}$} & \multicolumn{2}{|c|}{$\begin{array}{l}\text { Egg production } \\
\text { (No's) }\end{array}$} & \multicolumn{2}{|c|}{$\begin{array}{c}\text { Egg production } \\
(\%)\end{array}$} & \multirow[b]{2}{*}{ P Value } \\
\hline & 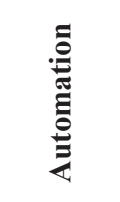 & 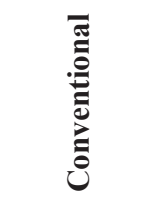 & 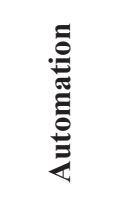 & 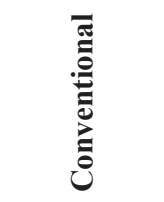 & \\
\hline 126 & 0 & 0 & 0 & 0 & \\
\hline 133 & 13.00 & 12.00 & 10.40 & 9.60 & 0.91 \\
\hline 140 & 30.25 & 28.42 & 24.20 & 22.74 & 0.28 \\
\hline 147 & $70.00^{\mathrm{A}}$ & $54.80^{\mathrm{B}}$ & $56.00^{\mathrm{A}}$ & $43.84^{\mathrm{B}}$ & 0.0001 \\
\hline 154 & $75.42^{\mathrm{A}}$ & $67.28^{\mathrm{B}}$ & $60.34^{\mathrm{A}}$ & $53.82^{\mathrm{B}}$ & 0.005 \\
\hline 161 & 90.28 & 83.57 & 72.22 & 66.86 & 0.48 \\
\hline 168 & 97.66 & 83.57 & 78.13 & 66.86 & 0.06 \\
\hline 175 & $99.42^{\mathrm{a}}$ & $86.14^{b}$ & $79.54^{\mathrm{a}}$ & $68.91^{\mathrm{b}}$ & 0.04 \\
\hline 182 & $102.14^{\mathrm{A}}$ & $92.85^{\mathrm{B}}$ & $81.71^{\mathrm{A}}$ & $74.28^{\mathrm{B}}$ & 0.0007 \\
\hline 189 & $104.00^{\mathrm{A}}$ & $94.00^{\mathrm{B}}$ & $83.20^{\mathrm{A}}$ & $75.20^{\mathrm{B}}$ & 0.0008 \\
\hline 196 & $102.57^{\mathrm{a}}$ & $98.70^{\mathrm{b}}$ & $82.06^{\mathrm{a}}$ & $78.96^{\mathrm{b}}$ & 0.05 \\
\hline 203 & 97.42 & 97.14 & 77.94 & 77.71 & 0.85 \\
\hline 210 & 95.22 & 96.57 & 76.18 & 77.26 & 0.81 \\
\hline 217 & 94.22 & 96.00 & 75.38 & 76.80 & 0.28 \\
\hline 224 & 92.14 & 91.00 & 73.71 & 72.80 & 0.35 \\
\hline 231 & 91.52 & 90.00 & 73.22 & 72.00 & 0.25 \\
\hline 238 & 90.50 & 88.50 & 72.40 & 70.80 & 0.35 \\
\hline 245 & 85.14 & 87.36 & 68.11 & 69.89 & 0.18 \\
\hline 252 & 84.14 & 86.47 & 67.31 & 69.18 & 0.22 \\
\hline 259 & 84.57 & 81.36 & 67.66 & 65.09 & 0.12 \\
\hline 266 & 82.52 & 79.00 & 66.02 & 63.20 & 0.09 \\
\hline 273 & 81.20 & 77.42 & 64.96 & 61.94 & 0.06 \\
\hline 280 & 77.57 & 74.71 & 62.06 & 59.77 & 0.46 \\
\hline $\begin{array}{l}\text { Mean } \\
\text { (S.E) }\end{array}$ & $\begin{array}{c}83.67 \pm \\
4.84\end{array}$ & $79.40 \pm 4.78$ & $\begin{array}{c}66.94 \pm \\
3.87\end{array}$ & $63.52 \pm 3.82$ & 0.52 \\
\hline
\end{tabular}

A,B-Means bearing different superscripts within rows differ significantly $(\mathrm{P} \leq 0.01)$; a,b- Means bearing different superscripts within rows differ significantly $(\mathrm{P} \leq 0.05)$.

Table 5(b): Effect of rearing systems (ARS \& CRS) on Hen Day egg production and Hen Housed egg production (\%)

\begin{tabular}{lll}
\hline Rearing system & HDEP $(\%)$ & HHEP $(\%)$ \\
\hline Automation & $66.93^{\mathrm{a}} \pm 0.26$ & $66.93^{\mathrm{A}} \pm 0.32$ \\
Conventional & $65.61^{\mathrm{b}_{1} \pm 0.99}$ & $63.52^{\mathrm{B}} \pm 2.40$ \\
P value & 0.04 & 0.008 \\
\hline
\end{tabular}

A,B-Means bearing different superscripts within rows differ significantly $(\mathrm{P} \leq 0.01)$; a,b- Means bearing different superscripts within rows differ significantly $(\mathrm{P} \leq 0.05)$.
Litter Quality: Litter quality analyzed based on the proximate analysis and Ecoli count and found significant difference (Table $6 \mathrm{a} \& 6 \mathrm{~b}$ ) among the two-rearing system $(\mathrm{P} \leq 0.01)$.The proximate analysis of built up litter was significantly higher $(\mathrm{P} \leq 0.01)$ in conventional rearing system than the automatic rearing system. The higher proximate values like crude protein, crude fat, crude fibre, total ash and energy value were mainly due to feed wastage in conventional rearing system which leads to elevation of these values. The results of the study of Ensimnger (1977); Devendra and Raghavan (1978); Lamidi (1995) all reported approximately 25 per cent crude protein for poultry litter. The differences in the proximate content of poultry litter used in this study (20 per cent) when compared to the findings of other authors as cited above could be attributed to the difference in the type of bedding material, feed wastage, the type of rations used, method of handling and method of processing and storage of the poultry litter. However, the feed wastage is the major attributed factor for the high value of proximate principles in the poultry litter in conventional rearing system. (Cole et al., 2009) claimed less feed wastage due to special patented designed which doesn't allow feed to drop outside the feeders. Saleh et al. (2002) who compared the nutritive contents of poultry litter obtained Crude Protein scores of 23 per cent. The total ash content provides important data and information about the quality of poultry litter. This is because it measures the mineral content of the litter. Ash is normally high in poultry litter because of the paddy husk. In this study, the ash content of the litter was 18.40 per cent in automatic rearing system to 19.09 per cent in conventional rearing system. Ash samples between 1525 percent are acceptable (Ruffin and McCaskey, 1990). This finding is in line with their recommendation and they further observed that high ash content (above 28 percent) too dry litter causes respiratory and eye irritation to the poultry flock. With respect to the Dry Matter content, the study observed a DM content of 79.70 to 81.8 per cent in automatic and conventional rearing system, respectively. This means that the poultry litter had 18.20 and 20.30 per cent moisture in automatic and conventional rearing system respectively. From earlier reports Ruffin and McCaskey (1990); Burdine et al. (1993); Bagley et al. (1994), it was concluded that moisture in the litter should be between 12 and 25 percent. Results obtained in the present study are strongly in agreement with their findings. The E.coli count in conventional system was significantly higher than 
Table 6a: Effect of rearing systems on Litter Quality parameters of experimental birds at the beginning of study

\begin{tabular}{|c|c|c|c|c|c|}
\hline \multirow[t]{2}{*}{ Sl. No. } & \multirow{2}{*}{$\begin{array}{l}\text { Proximate principle } \\
\text { and microbial load }\end{array}$} & $\begin{array}{c}\text { T1 } \\
\text { (Automation) }\end{array}$ & $\begin{array}{c}\mathrm{T} 2 \\
\text { (Conventional) }\end{array}$ & \multirow[t]{2}{*}{ P-value } & \multirow{9}{*}{$\begin{array}{l}\text { The result is not significant } \\
\text { at } p<0.05\end{array}$} \\
\hline & & Beginning of study & Beginning of study & & \\
\hline 1 & Moisture \% & $12.51 \pm 0.11$ & $12.41 \pm 0.13$ & 0.85 & \\
\hline 2 & $\mathrm{CP} \%$ & $3.10 \pm 0.01$ & $3.00 \pm 0.01$ & 0.69 & \\
\hline 3 & $\mathrm{CF} \%$ & $42.30 \pm 0.19$ & $42.30 \pm 0.21$ & 0.95 & \\
\hline 4 & $\mathrm{EE} \%$ & $2.41 \pm 0.02$ & $2.42 \pm 0.01$ & 0.92 & \\
\hline 5 & Ash $\%$ & $16.50 \pm 0.12$ & $16.40 \pm 0.13$ & 0.74 & \\
\hline 6 & E. coli $(\mathrm{CFU} / \mathrm{g})$ & 450 & 480 & 0.68 & \\
\hline 7 & Coccidial oocyst & 0.00 & 0.00 & - & \\
\hline
\end{tabular}

Table 6b: Effect of rearing systems on Litter Quality parameters of experimental birds at the end of the study

\begin{tabular}{|c|c|c|c|c|c|}
\hline \multirow{2}{*}{$\begin{array}{l}\text { Sl. } \\
\text { No. }\end{array}$} & \multirow{2}{*}{$\begin{array}{l}\text { Proximate principle } \\
\text { and microbial load }\end{array}$} & \multirow{2}{*}{$\begin{array}{c}\text { T1 } \\
\text { (Automation) } \\
\text { End of study }\end{array}$} & \multirow{2}{*}{$\begin{array}{c}\text { T2 } \\
\text { (Conventional) } \\
\text { End of study }\end{array}$} & \multirow[t]{2}{*}{ P value } & \multirow{9}{*}{$\begin{array}{l}\text { The result is significant at } \mathrm{p} \leq \\
.01 \text {. }\end{array}$} \\
\hline & & & & & \\
\hline 1 & Moisture \% & $18.20^{\mathrm{A}} \pm 0.23$ & $20.30^{\mathrm{B}} \pm 0.33$ & 0.002 & \\
\hline 2 & $\mathrm{CP} \%$ & $20.11^{\mathrm{A}} \pm 0.15$ & $23.12^{\mathrm{B}} \pm 0.21$ & 0.001 & \\
\hline 3 & $\mathrm{CF} \%$ & $26.62^{\mathrm{a}} \pm 0.11$ & $27.34^{\mathrm{b}} \pm 0.38$ & 0.02 & \\
\hline 4 & $\mathrm{EE} \%$ & $2.51^{\mathrm{A}} \pm 0.05$ & $2.83^{\mathrm{B}} \pm 0.03$ & 0.01 & \\
\hline 5 & Ash $\%$ & $18.40^{\mathrm{A}} \pm 0.17$ & $19.09^{\mathrm{B}} \pm 0.15$ & 0.004 & \\
\hline 6 & E. coli $(\mathrm{CFU} / \mathrm{g})$ & $4.2^{\mathrm{A}} \times 10^{5}$ & $5.1^{\mathrm{B}} \times 10^{7}$ & 0.01 & \\
\hline 7 & Coccidial oocyst & 0.00 & 0.00 & - & \\
\hline
\end{tabular}

A,B-Means bearing different superscripts within rows differ significantly ( $\mathrm{P} \leq 0.01)$; a,b- Means bearing different superscripts within rows differ significantly $(\mathrm{P} \leq 0.05)$.

in automatic rearing system $(\mathrm{P}<0.05)$. Bell et al. (2007) reported that drinking water, human handling and in ovo route are the important mode of transmission of $E$ coli. The usage of nipple drinkers in automatic rearing system reduces the microbial contamination. Controlling bacterial load is much more difficult with open drinker systems as they are exposed to contamination by faecal dust and the oral and nasal secretions of birds as they drink. Closed nipple systems have the advantage of reducing disease spread since these systems will always equipped with filtration system (Goan, 1994). This statement can be conclusive with the work of Macari and Amaral, (1997) who compared the nipple drinkers versus bell drinker in commercial poultry farms and concluded that E.coli count in bell drinkers $10^{5}$ times more than nipple drinker system. The oocyst of coccidia was not found during entire study period and concluded that there is no significant evidence to support the viability of oocyst in automatic and conventional rearing system. Alternatively, moisture is less than 20 per cent attributed to the non viability of the coccidial oocyst. Result of the study is in consonance with Reyna et al. (1983) who reported that viability of coccidial oocyst are 100 per cent declined in litter having moisture less than 20 per cent. The working time measurement for feeding was observed to be 8.4 man power minutes per day for $T_{1}$ group of automatic rearing system as compare to 22 minutes man power minutes per day in $T_{2}$ group of conventional rearing system. Machine known for precision and accuracy in less time, however no studies reported so far. Statistical analysis reveals that the values are highly significant $(\mathrm{P} \leq 0.01)$ among the treatments.

Liveability: The liveability rate (Table 7 ) of the experimental birds was significantly higher $(\mathrm{P} \leq 0.05)$ in automatic rearing system than the experimental birds in 
conventional rearing system. The high liveability rate in automatic rearing system is mainly due to less manhandling and human contamination. Nipple watering systems are more hygienic water delivery system for commercial poultry. (Cobb breeder management guide, 2009). This is in contrast with reports of (Tanaka and Hurnik, 1992; Abrahamsson et al., 1995), which found that mortality, can be low in alternative housing systems such as Aviary and enriched housing system.

Table 7: Effect of rearing systems on Liveability (\%) of HH260 birds

\begin{tabular}{llll}
\hline Rearing system & $\begin{array}{l}\text { Liveability } \\
\text { (per replicate) }\end{array}$ & $\begin{array}{l}\text { Total no. of } \\
\text { experimental } \\
\text { birds live on 40 } \\
\text { week }\end{array}$ & (In \%) \\
\hline Automation & $25.00^{\mathrm{a}} \pm 0.00$ & $125^{\mathrm{a}}$ & $100 \%$ \\
Conventional & $24.20^{\mathrm{b}} \pm 0.48$ & $121^{\mathrm{b}}$ & $96 \%$ \\
P value & 0.03 & & \\
\hline
\end{tabular}

a,b-Means bearing different superscripts within the column differ significantly $(\mathrm{P} \leq 0.05)$.

Table 8: Working time measurement of feeding, watering and medication

\begin{tabular}{llll}
\hline \multicolumn{3}{c}{ Working time measurement (Manpower Minutes/day) } \\
\hline Rearing system & Feeding & Watering & Medication \\
\hline Automation & $08.40^{\mathrm{A}} \pm 0.27$ & $02.00^{\mathrm{A}} \pm 0.00$ & $07.00^{\mathrm{A}} \pm 0.5$ \\
Conventional & $22.00^{\mathrm{B}} \pm 0.79$ & $61.20^{\mathrm{B}} \pm 1.55$ & $25.20^{\mathrm{B}} \pm 1.67$ \\
P value & 0.001 & 0.001 & 0.001 \\
\hline
\end{tabular}

A,B-Means bearing different superscripts within rows differ significantly $(\mathrm{P} \leq 0.01)$; a,b- Means bearing different superscripts within rows differ significantly $(\mathrm{P} \leq 0.05)$.

However, mortality is caused by several components and it is difficult to categorize the real causes according to housing systems. Another study from Tauson et al. (1999) found that the overall higher mortality of Lohmann Brown hens in floor pens than in cages is largely due to cannibalism and feather pecking with no difference between housing systems. To ensure health and optimum egg quality the water supplied to the hens should be of potable standard (Thiele and Pottguter, 2008). The overall symmetry and mechanisms of immune system in birds are relatively similar to those in mammals which is directly influenced by genetic, physiological, nutritional, and environmental factors (Qureshi et al., 1998; Rautenschlein et al., 2003). The immune system of birds is complex and is composed of several cells and soluble factors that must work together to produce a protective immune response. A well developed and functional immune system is important to poultry because most commercial flocks are raised under intensive rearing conditions. Under such conditions, the flocks are vulnerable to rapid spread of infectious agents and disease outbreaks (Rautenschlein et al., 2003). Contrary to these findings, Platz et al. (2009) reported that the assessment of healthiness of hens housed in furnished houses did not indicate any significant advantage over those housed in aviaries. The working time measurement for feeding was observed to be 8.4 man power minutes per day for $\mathrm{T}_{1}$ group of automatic rearing system as compare to 22 minutes man power minutes per day in $\mathrm{T}_{2}$ group of conventional rearing system. Machine known for precision and accuracy in less time, however no studies reported so far. Statistical analysis reveals that the values are highly significant $(\mathrm{P} \leq$ 0.01 ) among the treatments.

\section{CONCLUSION}

The result of the present study indicated that automation rearing system for commercial poultry is beneficial for eliciting optimum production performance in $\mathrm{HH}$ 260(white leg horn) Breeder birds. It accepted the hypothesis of the study that ARS housing have better productivity and profitability over conventional, this is testified by the general better FCR, egg production, liveability and litter quality in CCS houses.

\section{ACKNOWLEDGEMENTS}

Authors are thankful to the Director cum Joint Commissioner of Central Poultry Development Organization and Training Institute and Associate Professor and Head, Department of LPM, Veterinary College Bangalore for providing facilities and valuable inputs for conducting the trail.

\section{REFERENCES}

Abanikannda, O.T.F., Olutogun, O., Leigh, A.O. and Ajayi, L.A., 2007. Statistical modeling of egg weight and egg dimensions in commercial layers. Int. J. Poult Sci., 6(1): 59-63. 
Abrahamsson, P. and R. Tauson., 1995. Aviary systems and conventional cages for laying hens. Effects on production, egg quality, health and birds' location in three hybrids. Acta Agric. Scand., 45: 191-200

Abrahamsson, P., Tauson, R. and Elwinger, K. 1996. Effects on production, health and egg quality of varying proportions of wheat and barley in diets for two hybrids of laying hens kept in different housing systems. Acta Agric. Scand., 46(3): 173182.

Adam, I.Y.I., 2017. Effect of Deep-Litter Floor and Battery Cages System on the Productive Performance of Commercial Layers in Elobied, Sudan (Doctoral dissertation, University of Kordofan).

Ahammed, M., Chae, B.J., Lohakare, J., Keohavong, B., Lee, M.H., Lee, S.J., Kim, D.M., Lee, J.Y. and Ohh, S.J., 2014. Comparison of aviary, barn and conventional cage raising of chickens on laying performance and egg quality. Asian-Aus. J. Anim. Sci., 27(8): 1190-1196.

Anderson, K.E. and Adams, A.W., 1992. Effects of rearing density and feeder and waterer spaces on the productivity and fearful behaviour of layers. Poult. Sci., 71(1): 53-58.

Anderson, K.E. and Adams, A.W., 1994. Effects of floor versus cage rearing and feeder space on growth, long bone development, and duration of tonic immobility in single comb White Leghorn pullets. Poult. Sci., 73(7): 958-964.

Anonymous. 1997. Hubbard Breeder Management Guide. Hubbard Farms, Walpole, New: pp. 21-32.

Anonymous. 2009. Cobb Breeder Management Guide. Cobb Farms, Arkansas, USA: pp. 14-22

AOAC, 2003. Official methods of analysis of the association of official's analytical chemists, $17^{\text {th }} \mathrm{edn}$. Association of official analytical chemists, Arlington, Virginia.

Armstrong, D.V. and Quick, A.J., 1986. Time and motion to measure milking parlor performance. J. of Dairy Sci, 69(4): 1169-1177.

Aryal, S., 2018. MacConkey Agar-composition, principle, uses, preparation and colony morphology. Obtenido de Microbiologyinfo: Accesed on http://www. Microbiologyinfo. $\mathrm{com} / \mathrm{macconkey-agar-composition-principle-uses-}$ preparation-and-colony-morphology.

Basic Animal Husbandry and Fisheries Statistics. 2019, Government of India, New Delhi, India.

Bell, D.D., Weaver, W.D. and North, M.O. 2002. Commercial chicken meat and egg production. $4^{\text {th }}$ Ed Springer Science \& Business Media, pp. 25-850.

Bell, D.D., Weaver, W.D. and North, M.O. 2007. Commercial chicken meat and egg production. $5^{\text {th }}$ Ed Springer Science \& Business Media, pp. 140-780

Burdine, W.B., Bagley, C.P. and Evans, R.R., 1993. Weanling heifer performance on chicken litter supplements. Livestock Day Rep. MAFES Bull., 243: 24.

Castellini, C., Perella, F., Mugnai, C. and Dal Bosco, A., 2006. Welfare, productivity and qualitative traits of egg in laying reared under different rearing systems. In Proc. 12th Eur. Conf. on Poultry, Sept, 2006..Verona, Italy, pp. 592-598

Clark, C.E.F., Farina, S.R., Garcia, S.C., Islam, M.R., Kerrisk, K.L. and Fulkerson, W.J. 2016. A comparison of conventional and automatic milking system pasture utilization and pre and post grazing pasture mass. Grass and Forage Sci., 71(1): 153-159.

Cole, T.J., Kreger, L.L. and Bird, C.R., CTB Inc, 2009. Pan breeder feeder. U.S. Patent 7,584,716.

Devendra, C. and Raghavan, G.V. (1978). Agricultural byproducts in South East Asia: Availability, Utilisation and potential value. World. Rev. Anim. Prod., 14: 11-28.

Du Plessis, P.H.C. and Erasmus, J., 1972. The relationship between egg production, egg weight and body weight in laying hens. World. Poult. Sci. J., 28(3): 301-310.

Đukić-Stojčić, M., Perić, L., Bjedov, S. and Milošević, N., 2009. The quality of table eggs produced in different housing systems. Biotech. Anim. Husbandry., 25(5/6): 1103-1108.

Eekeren, N.V., Maas, A., Saatkamp, H.W. and Verschuur, M., 2006. Small-scale chicken production. $4^{\text {th }}$ Ed, Agromisa/ CTA, Wageningen,. pp.1-91

Englmaierová, M., Tůmová, E., Charvátová, V. and Skřivan, M. 2014. Effects of laying hens housing system on laying performance, egg quality characteristics, and egg microbial contamination. Czech J. Anim. Sci., 59: 345-352.

Ensimnger, M.E., 1977. Anim. Sci. ( $7^{\text {th }}$ ed). The Interstate printers and publishers, USA. pp. 860-871.

Gerzilov, V., Datkova, V., Mihaylova, S. and Bozakova, N. 2012. Effect of poultry housing systems on egg production. Bulgarian J. Agri. Sci., 18(6): 953-957.

Goan, C. 1994. Management of nipple watering systems for broilers. Agricultural Extension Service, University of Tennessee. Accessed on http://www.utextension.utk.edu/ publications/pbfiles/pb1, 533.

Harms, R.H. 1984. The influence of feeding program on peak production and avoiding sudden declines in production with broiler breeders. Poult. Sci., 63(8): 1667-1668.

Haug, A., Williams, R.B. and Larsen, S. 2006. Counting coccidial oocysts in chicken faeces: a comparative study of a standard McMaster technique and a new rapid method. Vet. Parasitol., 136(3-4): 233-242.

Hovi, M., Sundrum, A. and Thamsborg, S.M. 2003. Animal health and welfare in organic livestock production in Europe: current state and future challenges. Livestock Prod. Sci., 80(1-2): 41-53. 
Hurnik, G.I., Reinhart, B.S. and Hurnik, J.F. 1978. Relationship between albumen quality and hatchability in fresh and stored hatching eggs. Poult. Sci., 57(4): 854-857.

Idowu, P.A., Mpayipheli, M. and Muchenje, V. 2018. Practices, housing and diseases within indigenous poultry production in Eastern Cape, South Africa. J. Agric. Sci., 10: 111-121.

Jahan, S., Islam, F., Bhuiyan, M.S.A. and Bhuiyan, A.K.F.H., 2017. Productive and reproductive performances of indigenous chicken in the rural condition of Bangladesh. Bangladesh J. Anim. Sci., 46(2): 121-127.

Kekeocha, C.C. 1984. Pfizer poultry production handouts. Published by Pfizer Corporation, Nairobi, Kenya, pp. 165166.

Kristensen, I.S. and Sillebak-Kristensen, I. 1996. Ecological production of eggs and crops. Technical and economic farm results in 1994-95. Beretningfra Statens Husdyrbrugsforsog., 730: 93-163

Lacin E, Yildiza, Esenbugan and Macitm. 2008. The effects of differences in the initial body weight of groups on laying performance and egg quality parameters of Lohmann laying hens. Czech J. Anim. Sci., 53(11): 466-471.

Lamidi, O.S. 1995. Poultry Manure as Supplement for Cattle Grazing the Natural Pastures. M Sc Thesis, Department of Animal Science, Ahmadu Bello University, Zaria, Nigeria..

Lampkin, N., Padel, S., Fowler, S., Rajah, K., Mcdougall, I., Langstaff, L., O'regan, T. and Sharples, T. 1997. Organic Poultry Production; Report to MAFF; Welsh Institute of Rural Studies, University of Wales: Aberystwyth, UK.

Leeson, S. and Summers, J., 1991. Commercial Poultry Nutrition. $3^{\text {rd }}$ Ed. Nottingham University Press, Guelph. Ontario., pp. 190-332.

Leeson, S. and Summers, J., 2009. Commercial Poultry Nutrition $4^{\text {th }}$ Ed. Nottingham University Press, Guelph. Ontario., $p p$. 284-375.

Macari, M. and Amaral, L.A. 1997. Importancia da Qualidade da Agua Na Criacao de Frangos de Corte: Tipos, Vantagens e Desvantagens. Anais da Apinco Campinas., pp. 121-143.

Meunier, Salaün, M.C., Huon, F. and Faure, J.M. 1984. Lack of influence of pullet rearing conditions on the hen's performance. Br. Poult. Sci., 25(4): 541-546.

Mugnai, C., Dal Bosco, A. and Castellini, C. 2009. Effect of rearing system and season on the performance and egg characteristics of Ancona laying hens. Italian J. Anim. Sci., 8(2): 175-188.

Neijat, M., House, J.D., Guenter, W. and Kebreab, E. 2011. Production performance and nitrogen flow of Shaver White layers housed in enriched or conventional cage systems. Poult. Sci., 90(3): 543-554.
Petek, M. 1999. Production traits and economic efficiencies of different genotypes of layers reared by enterprises in Bursa province and it's near vicinity. Veteriner Fakultesi Dergisi Uludag Universitesi., 18(1-2): 65-77.

Platz, S., Heyn, E., Hergt, F., Weigl, B. and Erhard, M., $2009.3^{\text {rd }}$ Ed. Comparative study on the behavior, health and productivity of laying hens in a furnished cage and an aviary system. Berl Munch Tierarztl Wochenschr., 122(7-8): 235240.

Qureshi, M.A., Hussain, I. and Heggen, C.L., 1998. Understanding immunology in disease development and control. Poult. Sci., 77(8): 1126-1129.

Rakonjac, S., Bogosavljević-Bošković, S., Škrbić, Z., Perić, L., Dosković, V., Petrović, M.D. and Petričević, V. 2017. The effect of the rearing system, genotype and laying hens age on the egg weight and share of main parts of eggs. Acta Agric Scand A., 22(44): 185-192.

Rautenschlein, S., Yeh, H.Y. and Sharma, J.M., 2003. Comparative immunopathogenesis of mild, intermediate, and virulent strains of classic infectious bursal disease virus. Avian Dis., 47(1): 66-78.

Reyna, P.S., Mcdougald, L.R. and Mathis, G.F. 1983. Survival of coccidia in poultry litter and reservoirs of infection. Avian Dis., 464-473.

Ruffin, B.G. and Mccaskey, T.A. 1990. Feeding broiler litter to cattle. Circular ANR-Alabama Cooperative Extension Service, Auburn University (USA).

Saleh, H.M., Elwan, K.M., El-Fouly, H.A., Ibrahim, I.I., Salama, A.M. and Elashry, M.A. 2002. The use of poultry waste as a dietary supplement for ruminants field evaluation of animal feed supplementation packages, pp. 43.

Scanes, C.G. 2016. Biology of stress in poultry with emphasis on glucocorticoids and the heterophil to lymphocyte ratio. Poult. Sci., 95(9): 2208-2215.

Shah, S., Westerman, P.W. and Parsons, J. 2006. Poultry litter amendments. NC Cooperative Extension Service

Singh, R.V., Saxena, V.K. and Sharma, D., 2009. Technological developments in the poultry sub-sector; In technology options for sustainable livestock production in India.

Sonkamble, V.V., Srivastava, A.K., Pawar, M.M., Chauhan, H.D., Ankuya, K.J. and Jain, A.K., 2020. Effect of cage or deep litter housing on production performance of White Leghorn chickens. J. Anim. Res., 10(2): 263-268.

Sosnówka-Czajka, E., Herbut, E. and Skomorucha, I. 2010. Effect of different housing systems on productivity and welfare of laying hens. Ann Anim Sci., 10: 349-60.

Statistics, B.B.A.H., $20^{\text {th }}$ Livestock census (2019). DAHDF, Ministry of Agriculture, pp. 65-73. 
Tactacan, G.B., Guenter, W., Lewis, N.J., Rodriguez-Lecompte, J.C. and House, J.D. 2009. Performance and welfare of laying hens in conventional and enriched cages. Poult. Sci., 88(4): 698-707.

Tanaka, T. and Hurnik, J.F., 1992. Comparison of behaviour and performance of laying hens housed in battery cages and an aviary. Poult. Sci., 71(2): 235-243.

Tauson, R., Wahlström, A. and Abrahamsson, P. 1999. Effect of two floor housing systems and cages on health, production, and fear response in layers. J. Appl. Poult. Res., 8(2): 152159.
Thiele, H.H. and Pottgüter, R. 2008. Management recommendations for laying hens in deep litter, perchery and free range systems. Lohman Information, 43(1): 53.

Tyagi, P.K., Shrivastav, A.K., Tyagi, P.K., Mandal, A.B. and Elangovan, A.V. 2009. Near infrared reflectance (NIR) spectroscopy to predict the metabolisable energy content in poultry feeds. Indian J. Poul. Sci., 44(1): 45-48.

Van Krey, H.P. and Weaver Jr, W.D. 1988. Effects of feeder space on body weight uniformity of broiler breeder pullets during an alternate day feeding program. Poult. Sci., 67(7): 996-1000. 
